\title{
Teaching Video NeuroImages: Intralabyrinthine schwannoma masquerading as Ménière disease
}

Sun-Uk Lee, MD, Hyo-Jung Kim, PhD, Jeong-Yoon Choi, MD, PhD, Jae-Jin Song, MD, PhD,

Byung-Se Choi, MD, PhD, and Ji-Soo Kim, MD, PhD

Neurology ${ }^{\circledR}$ 2020;94:e1227-e1228. doi:10.1212/WNL.0000000000009095

Figure Patient findings
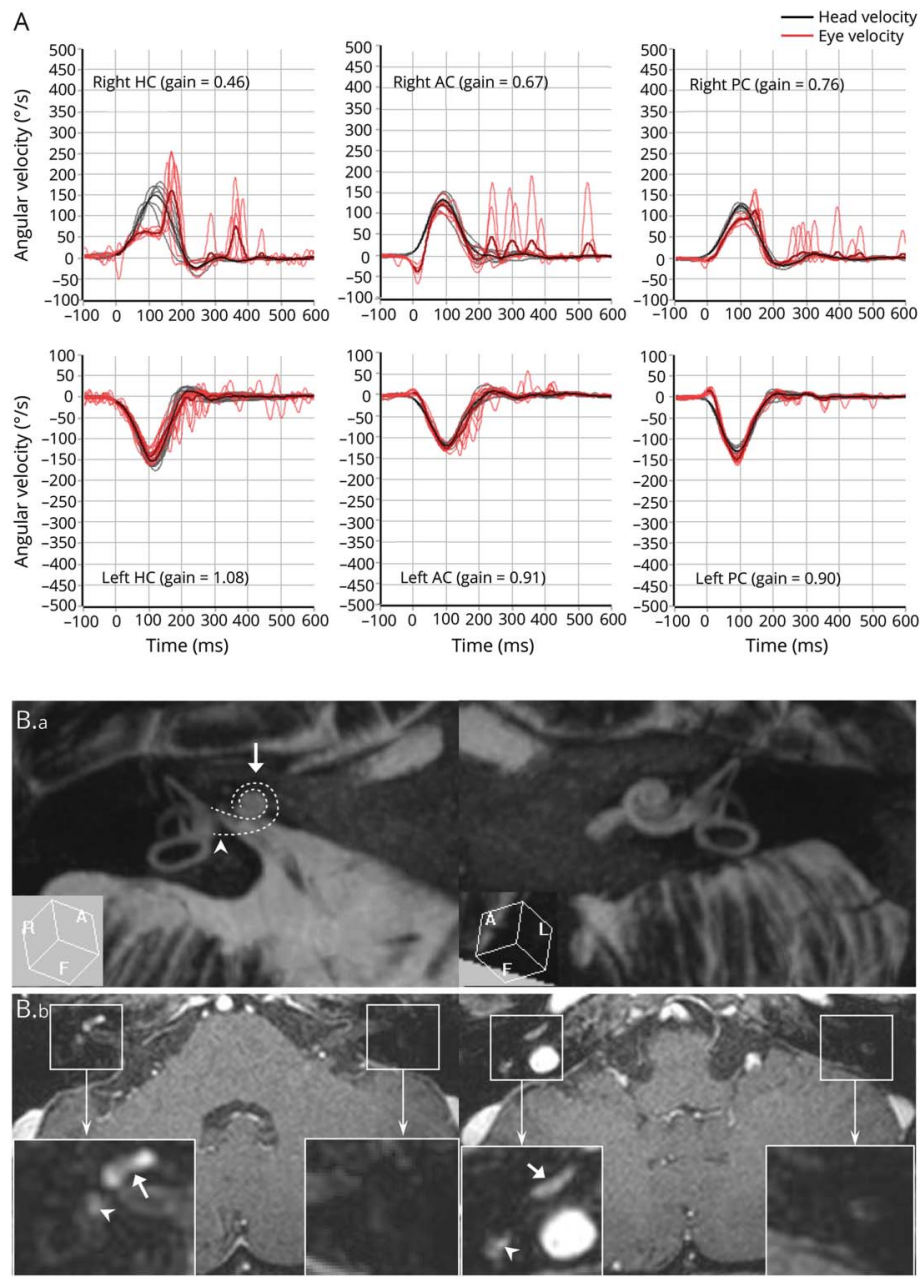

(A) Video head-impulse tests are positive to the right. $\mathrm{AC}=$ anterior canal; $\mathrm{HC}=$ horizontal canal; $\mathrm{PC}=$ posterior canal. (B) MRIs show a loss of T2 signal intensity at the basal cochlea (dashed lines and arrow) and vestibule (arrowhead) in the right ear (B.a) and abnormal enhancements in the corresponding areas (B.b).

A 56-year-old woman presented with recurrent spontaneous vertigo, fluctuating tinnitus, and ear fullness. Examination showed spontaneous nystagmus beating leftward and counter-clockwise without fixation, which changed into right-beating during rightward gaze and after hyperventilation (video 1). She also showed positive head impulse tests for

\section{Correspondence}

Dr. J.-S. Kim

jisookim@snu.ac.kr

\section{MORE ONLINE}

\section{- Video}

$\rightarrow$ Teaching slides

links.lww.com/WNL/B57

From the Department of Neurology (S.-U.L.), Korea University Medical Center, Seoul; and Research Administration Team (H.-J.K.), Dizziness Center, Clinical Neuroscience Center (J.Y.C., J.-S.K.), and Departments of Neurology (J.-Y.C., J.-S.K.), Otolaryngology-Head and Neck Surgery (J.-J.S.), and Radiology (B.-S.C.), Seoul National University Bundang Hospital, and Department of Neurology, Seoul National University College of Medicine (S.-U.L., J.-Y.C., J.-S.K.), Seongnam, South Korea.

Go to Neurology.org/N for full disclosures. Funding information and disclosures deemed relevant by the authors, if any, are provided at the end of the article. 
all semicircular canals on the right side (figure, A), right caloric paresis of $94 \%$, and right sensorineural hearing loss from schwannoma restricted to right labyrinth (figure, B). Intralabyrinthine schwannoma is a rare and underrecognized cause of recurrent audiovestibulopathy, masquerading as Ménière disease. ${ }^{1}$ High-resolution MRIs allow antemortem diagnosis, ${ }^{2}$ and labyrinthectomy may be attempted when refractory with medication. ${ }^{1}$

This study followed the tenets of the Declaration of Helsinki and was performed according to the guidelines of the institutional review board of Seoul National University Bundang Hospital (1902/523-109).

\section{Study funding}

This study was supported by the Basic Science Research Program through the National Research Foundation of Korea (NRF) funded by the Ministry of Education, Science and Technology (no. NRF2016R1D1A1B04935568).

\section{Disclosure}

S. Lee, H. Kim, J. Choi, J. Song, and B. Choi report no disclosures relevant to the manuscript. J. Kim serves as an associate editor of Frontiers in Neuro-otology and on the editorial boards of the Journal of Clinical Neurology, Frontiers in Neuro-ophthalmology, Journal of Neuro-ophthalmology, Journal of Vestibular Research, Journal of Neurology, and Medicine. Go to Neurology.org/ $\mathrm{N}$ for full disclosures.
Appendix Authors

\begin{tabular}{|c|c|c|c|}
\hline Name & Location & Role & Contribution \\
\hline $\begin{array}{l}\text { Sun-Uk } \\
\text { Lee, MD }\end{array}$ & $\begin{array}{l}\text { Korea University } \\
\text { Medical Center, Seoul, } \\
\text { South Korea }\end{array}$ & Author & $\begin{array}{l}\text { Analyzed and interpreted } \\
\text { the data and wrote the } \\
\text { manuscript }\end{array}$ \\
\hline $\begin{array}{l}\text { Hyo- } \\
\text { Jung } \\
\text { Kim, } \\
\text { PhD }\end{array}$ & $\begin{array}{l}\text { Seoul National } \\
\text { University Bundang } \\
\text { Hospital, Seongnam, } \\
\text { South Korea }\end{array}$ & Author & $\begin{array}{l}\text { Analyzed and } \\
\text { interpreted the data, } \\
\text { and revised the } \\
\text { manuscript }\end{array}$ \\
\hline $\begin{array}{l}\text { Jeong- } \\
\text { Yoon } \\
\text { Choi, } \\
\text { MD, PhD }\end{array}$ & $\begin{array}{l}\text { Seoul National } \\
\text { University Bundang } \\
\text { Hospital, Seongnam, } \\
\text { South Korea }\end{array}$ & Author & $\begin{array}{l}\text { Analyzed and } \\
\text { interpreted the data, } \\
\text { and revised the } \\
\text { manuscript }\end{array}$ \\
\hline $\begin{array}{l}\text { Jae-Jin } \\
\text { Song, } \\
\text { MD, PhD }\end{array}$ & $\begin{array}{l}\text { Seoul National } \\
\text { University Bundang } \\
\text { Hospital, Seongnam, } \\
\text { South Korea }\end{array}$ & Author & $\begin{array}{l}\text { Analyzed and } \\
\text { interpreted the data, } \\
\text { and revised the } \\
\text { manuscript }\end{array}$ \\
\hline $\begin{array}{l}\text { Byung- } \\
\text { Se Choi, } \\
\text { MD, PhD }\end{array}$ & $\begin{array}{l}\text { Seoul National } \\
\text { University Bundang } \\
\text { Hospital, Seongnam, } \\
\text { South Korea }\end{array}$ & Author & $\begin{array}{l}\text { Analyzed and } \\
\text { interpreted the data, } \\
\text { and revised the } \\
\text { manuscript }\end{array}$ \\
\hline $\begin{array}{l}\text { Ji-Soo } \\
\text { Kim, } \\
\text { MD, PhD }\end{array}$ & $\begin{array}{l}\text { Seoul National } \\
\text { University Bundang } \\
\text { Hospital, Seongnam, } \\
\text { South Korea }\end{array}$ & Author & $\begin{array}{l}\text { Designed and } \\
\text { conceptualized the study, } \\
\text { interpreted the data, and } \\
\text { revised the manuscript }\end{array}$ \\
\hline
\end{tabular}

\section{References}

1. Lee SU, Bae YJ, Kim HJ, et al. Intralabyrinthine schwannoma: distinct features for differential diagnosis. Front Neurol 2019;10:750.

2. Salzman K, Childs A, Davidson H, Kennedy R, Shelton C, Harnsberger H. Intralabyrinthine schwannomas: imaging diagnosis and classification. AJNR Am J Neuroradiol 2012;33:104-109. 


\section{Neurology}

\section{Teaching Video NeuroImages: Intralabyrinthine schwannoma masquerading as Ménière disease}

Sun-Uk Lee, Hyo-Jung Kim, Jeong-Yoon Choi, et al. Neurology 2020;94;e1227-e1228 Published Online before print March 4, 2020 DOI 10.1212/WNL.0000000000009095

This information is current as of March 4, 2020

\section{Updated Information \&} Services

\section{References}

Subspecialty Collections

Permissions \& Licensing

Reprints including high resolution figures, can be found at: http://n.neurology.org/content/94/11/e1227.full

This article cites 2 articles, 1 of which you can access for free at: http://n.neurology.org/content/94/11/e1227.full\#ref-list-1

This article, along with others on similar topics, appears in the following collection(s):

All Neurotology

http://n.neurology.org/cgi/collection/all_neurotology

Audition

http://n.neurology.org/cgi/collection/audition

Tinnitus

http://n.neurology.org/cgi/collection/tinnitus

Vertigo

http://n.neurology.org/cgi/collection/vertigo

Information about reproducing this article in parts (figures,tables) or in its entirety can be found online at:

http://www.neurology.org/about/about_the_journal\#permissions

Information about ordering reprints can be found online:

http://n.neurology.org/subscribers/advertise

Neurology ${ }^{\circledR}$ is the official journal of the American Academy of Neurology. Published continuously since 1951, it is now a weekly with 48 issues per year. Copyright (C 2020 American Academy of Neurology. All rights reserved. Print ISSN: 0028-3878. Online ISSN: 1526-632X.

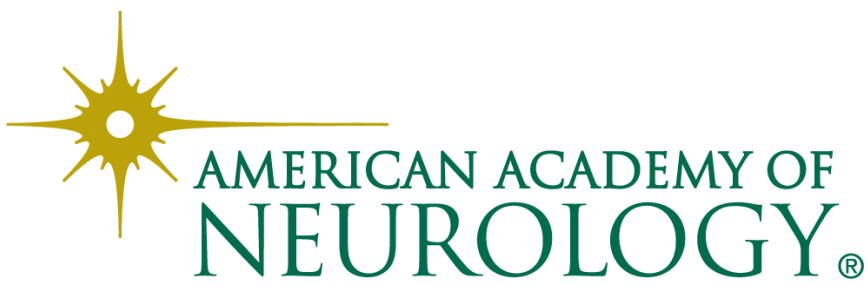

